[Research Note]

\title{
Screening of Supports and Additives for Heteropoly Acid Catalysts for Friedel-Crafts Reaction by High-throughput Screening and Data Mining
}

\author{
Kohji OMATA* \\ Dept. of Applied Chemistry, Graduate School of Engineering, Tohoku University, Aoba 6-6-07, Aramaki, Aoba-ku, Sendai 980-8579, JAPAN
}

(Received September 14, 2010)

\begin{abstract}
Friedel-Crafts alkylations are very important reactions which are widely used in the production of fine chemicals, intermediates, and petrochemicals. Solid catalysts should be developed for greening of these chemical processes. We previously developed a high-throughput screening system (HTS) and had been screening solid catalysts for benzylation of anisole by benzyl alcohol. In the present study, supports and additives for 12 tungstophosphoric acid (HPA) catalysts were screened by HTS and data mining tools using principal component analysis, radial basis function network, and support vector machine. These methods identified Re-HPA/activated carbon with the highest activity, which was experimentally confirmed.
\end{abstract}

\section{Keywords}

Friedel-Crafts reaction, High-throughput screening, Principal component analysis,

Radial basis function network, Support vector machine

\section{Introduction}

The Friedel-Crafts reactions are very important reactions which are widely used in the production of fine chemicals, intermediates, and petrochemicals. Typical catalysts for the Friedel-Crafts reactions are available in the liquid phase. The usage of over-stoichiometric amounts of these acids generates several problems such as corrosion, separation, and waste disposal. Therefore, to develop environmentally benign processes, active and green solid acid catalysts are required. Ionexchanged clays ${ }^{1), 2)}$ are highly efficient catalysts and zeolites show unique shape selectivity in spite of the low activity imposed by the diffusivity limit. Among the H-type zeolites, $\beta$ zeolite has properties as an anticoking catalyst $\mathrm{t}^{3)}$. Other mesoporous materials such as SBA- ${ }^{4)}$ and transition metal oxides are other known types of catalysts ${ }^{5), 6)}$.

The high-throughput screening (HTS) approach is useful to estimate the catalytic properties of new materials. We previously developed the HTS method using test tubes and a dry bath to optimize the catalyst composition of oxides for benzylation of anisole by benzyl alcohol ${ }^{7), 8)}$. The ohmic heating was then replaced by rapid microwave heating to accelerate the screening, which showed that Fe or Sn containing montmorillonite have high activity ${ }^{9}$. Then the development of successive catalyst screening revealed that phosphotungstate

*E-mail: omata@erec.che.tohoku.ac.jp
(HPA) shows higher activity. In the present study, we describe the screening of support and additives for HPA catalyst for benzylation of anisole by benzyl alcohol using the HTS method with test tubes and data mining tools.

Catalytic phenomena are generally very complicated because many non-linear parameters are involved. Therefore, the catalytic activity or selectivity of a new catalyst is quite difficult to predict based on previous experimental results. We have been using $\mathrm{RBFN}^{10)}$-17) to investigate the relationship between the activity and physicochemical properties of elements which are used as additives to catalysts. These properties should affect the catalytic properties such as surface area, metal dispersion, electronic state, morphology, thermal stability, affinity to supports, and others, and these catalytic properties then determine the catalytic activities. Therefore, the properties of elements should be correlated to the catalytic performance, although through quite complicated non-linear relationships. Catalysts were prepared using elements with known properties, and the parameters of a RBFN were tuned using the physicochemical properties and the catalytic performance. The tuning process is usually called "training" because of the association with the learning process of the human brain. The important point is that the variety of training elements are selected according to the orthogonal concept. For example, all elements can be clustered by the k-means clustering method, and some elements can be selected as the representative of each 
cluster. Then the relationship between the principal component of the physicochemical properties of elements and the activity of the catalyst containing the representative element can be quantified by RBFN and SVM. This procedure will be used in the present study.

\section{Experimental Method}

\section{1. HTS for Support of HPA Catalyst}

Screening for the support of HPA catalyst was performed in test tubes used for the preparation and activity test of catalysts. A test tube $(15 \mathrm{~mm}$ diameter $)$ was charged with 12 tungsto (VI) phosphoric acid $n$-hydrate (Wako Pure Chemical Industries, Ltd., HPA) (15 mg) and ethanol $(1 \mathrm{~mL})$. Then a support $(50 \mathrm{mg})$ was impregnated with the solution and dried at $90^{\circ} \mathrm{C}$, followed by washing with ethanol $(2 \mathrm{~mL})$ three times at room temperature to remove the free HPA. Japan Reference Catalysts (Catalysis Society of Japan) such as H-type $\beta$ zeolite (JRC-Z-HB25), H-type ZSM-5 (JRC-Z590H), magnesia (JRC-MGO-4-500A), zirconia (JRC-ZRO-1), silica A (JRC-SIO-5), alumina A (JRC-ALO-1A), alumina B (JRC-ALO-2), alumina C (JRC-ALO-7), were used as the support. Commercially available titania A (ST01, Ishihara Sangyo), titania B (anatase, Wako Pure Chemical Industries), silica B (P-10, Fuji Silysia Chemical Ltd.), silica C (ID, Fuji Davison), silica D (Q15, Fuji Silysia Chemical Ltd.), activated carbon A (BAC-LP Kureha Corp.), and activated carbon B (GC Kuraray Coal, Kuraray Chemical Co., Ltd., AC) were also used. Activity tests were conducted in other test tubes in a dry bath at $130^{\circ} \mathrm{C}$ using anisole $(2.0 \mathrm{~g})$ and benzyl alcohol $(0.2 \mathrm{~g})$. After the reaction, the test tube was cooled quickly in water. The products were analyzed by gas chromatography (Shimadzu GC-8A, Ar carrier, Dexil $300 \mathrm{GC}$ packed column at $170^{\circ} \mathrm{C}$ ) equipped with a flame ionization detector. The main products were benzyl anisoles, with small amounts of dibenzyl ether. The yields of benzyl anisoles and dibenzyl ether were calculated on the basis of the benzyl group.

\section{2. HTS for Additive of Supported HPA Catalyst}

Screening of additives for HPA supported on activated carbon (HPA/AC) was conducted using statistical language $\mathrm{R}^{18)}$ as the data mining tools in the next three steps.

\section{Step 1: preparation of input data}

At first 64 elements were selected as candidates for the additives to supported HPA catalyst. Physicochemical properties ${ }^{19), 20)}$ such as oxide formation enthalpy (FE, kJ/mol), 1st ionization energy (1I, eV), 2nd ionization energy (2I, eV), electronegativity (EN, -), electric dipole polarizability $\left(\mathrm{ED}, \AA^{3}\right.$ ), boiling point (BP, K), melting point (MP, K), specific heat capacity $(\mathrm{HC}, \mathrm{J} / \mathrm{g} / \mathrm{K})$, heat of fusion $(\mathrm{HF}, \mathrm{kJ} / \mathrm{mol})$, heat of vapor-
Table 1 Data File for Data Mining Saved with CSV Format

\begin{tabular}{ccccccc}
\hline & $\mathrm{A}$ & $\mathrm{B}$ & $\cdots$ & $\mathrm{P}$ & $\mathrm{Q}$ & $\mathrm{R}$ \\
\hline 1 & $\mathrm{FE}$ & $1 \mathrm{I}$ & $\cdots$ & $\mathrm{VA}$ & activity & symbol \\
2 & 417.98 & 5.139 & $\cdots$ & 1 & 17.9 & $\mathrm{Na}$ \\
$\vdots$ & $\vdots$ & $\vdots$ & $\vdots$ & $\vdots$ & $\vdots$ & $\vdots$ \\
64 & 218.06 & 7.416 & $\cdots$ & 3 & & $\mathrm{~Pb}$ \\
65 & 191.29 & 7.285 & $\cdots$ & 3 & & $\mathrm{Bi}$ \\
\hline
\end{tabular}

ization ( $\mathrm{HV}, \mathrm{kJ} / \mathrm{mol}$ ), thermal conductivity (TC, W/ $\mathrm{mK})$, covalent radius $(\mathrm{CR}, \mathrm{pm})$, density $\left(\mathrm{DS}, \mathrm{g} / \mathrm{cm}^{3}\right)$, ionic radius (IR, pm), atomic weight (AW, g/mol), and valence of ion (VA, -) were used to characterize each element. For data mining, properties and activity were recorded in a 'data.csv' file with symbols as shown in Table 1 illustrating a part of the csv file. Every property was normalized (mean $=0$ and variance $=1$ ) at the step of principal component analysis, so the units of properties were eliminated. Activity was also normalized to 0-1 for the response of the output of RBFN or SVM. Then, principal component analysis was conducted using the prcomp ( ) function to find the important factors in the physicochemical properties of the elements. The contribution of 5 principal components accounted for over $85 \%$ of total eigenvalues, so these 5 components were used as input data.

\section{Step 2: activity test}

Based on the 5 principal components, elements in the periodic table were categorized into 7 groups by k-means clustering according to Hartigan-Wong ${ }^{21)}$ using the kmeans( ) function, because a category containing only one member appeared if the categorization included 8 or more groups. One or two elements from each category were selected as training elements and used for catalyst preparation. The representative elements of each category were selected because of the availability, solubility, decomposition temperature, toxicity, and so on. For impregnation on the supported HPA catalyst, $\mathrm{Na}, \mathrm{Mg}, \mathrm{Mn}, \mathrm{Zn}, \mathrm{Pd}, \mathrm{Sn}, \mathrm{Cs}, \mathrm{Pr}$, and W were selected as training elements. $\mathrm{Bi}$ and $\mathrm{Re}$ was selected as validation elements. Sodium acetate trihydrate, magnesium acetate tetrahydrate, manganese (II) acetate tetrahydrate, anhydrous zinc acetate, palladium (II) nitrate, cesium acetate, praseodymium (III) acetate dihydrate, tungstic acid, bismuth (III) acetate oxide (Wako Pure Chemical Industries), tin (II) acetate, and rhenium (VII) oxide (Strem Chemicals) were used as received without further purification. Support (AC, activated carbon B) was impregnated in an ethanol $(1 \mathrm{~mL})$ solution of HPA $(8 \mathrm{mg})$ and the additive element salt $(5 \mu \mathrm{mol})$. The solution was dried at $90^{\circ} \mathrm{C}$ and then the supported catalyst was transferred to another test tube followed by reaction without pretreatment.

\section{Step 3: training and prediction}

Finally the 5 principal components of the physicochemical properties and the results of activity tests of 9 


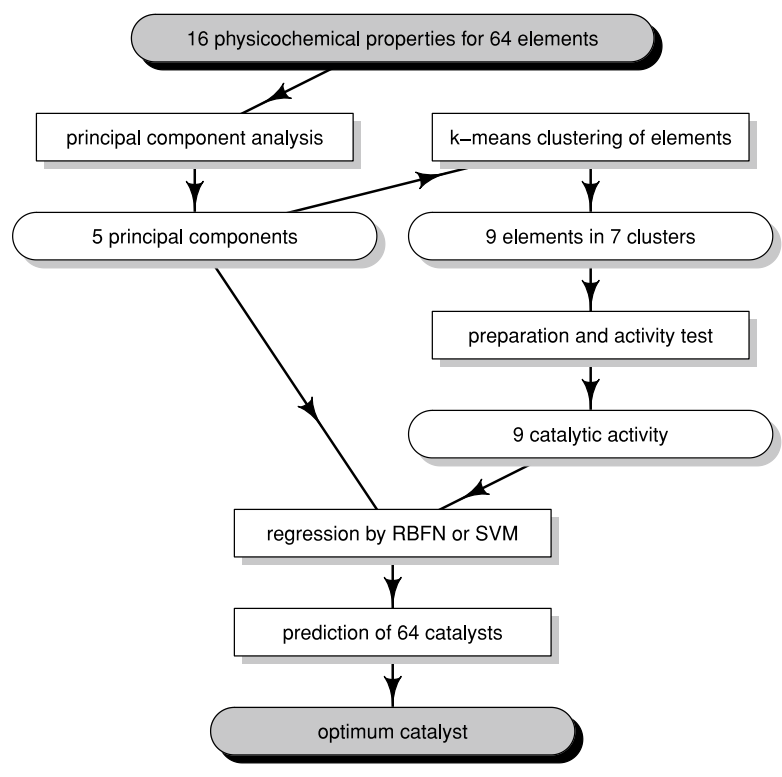

Fig. 1 Flow Chart for Data Mining

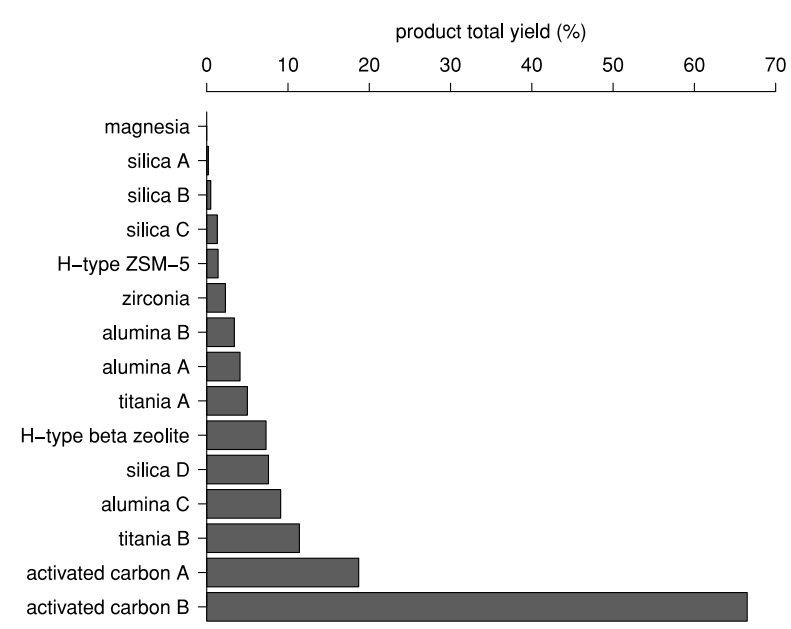

Fig. 2 Screening of Support at $130^{\circ} \mathrm{C}$ for HPA Catalyst

catalysts were used to find the optimum inner parameters of the RBFN and SVM. Then the RBFN and SVM were used to predict the activity of additives on HPA/AC catalyst by virtual screening. These processes are diagrammed in Fig. 1 and the codes of R are listed in the Appendix section.

\section{Results and Discussion}

\section{1. HTS for Support of HPA Catalyst}

Figure 2 summarizes the results of the screening of supports. The catalysts were not calcined in air at high temperature to avoid the thermal damage, so to eliminate the time-consuming step in HTS, a part of the HPA would be liberated from the support during the liquid phase reaction. Therefore, catalysts were washed with ethanol three times before reaction to
Table 2 Screening of Additives for HPA/AC Catalyst

\begin{tabular}{ccc}
\hline Additive & $\mathrm{BA}^{\mathrm{a})}[\%]$ & $\mathrm{BE}^{\mathrm{a})}[\%]$ \\
\hline $\mathrm{Cs}$ & 0.0 & 0.0 \\
$\mathrm{Mg}$ & 0.0 & 0.0 \\
$\mathrm{Mn}$ & 0.0 & 0.0 \\
$\mathrm{Zn}$ & 0.2 & 0.1 \\
$\mathrm{Na}$ & 0.4 & 0.2 \\
$\mathrm{Pr}$ & 28.0 & 4.1 \\
$\mathrm{Sn}$ & 56.1 & 5.6 \\
$\mathrm{Pd}$ & 57.0 & 5.2 \\
$\mathrm{~W}$ & 62.8 & 4.4 \\
\hline
\end{tabular}

a) Benzyl anisoles and benzyl ether at $130^{\circ} \mathrm{C}$.

Table 3 Prediction of Benzyl Anisole Yield of HPA/AC Catalysts at $130^{\circ} \mathrm{C}$

\begin{tabular}{lccc}
\hline Additive & Experimental & by RBFN & by SVM \\
\hline training data & & & \\
Sn & 56.1 & 56.1 & 49.8 \\
Pd & 57.0 & 57.0 & 50.7 \\
W & 62.8 & 62.8 & 56.5 \\
validation data & & & \\
Bi & 59.4 & 66.1 & 54.7 \\
Re & 64.1 & 62.3 & 50.4 \\
\hline
\end{tabular}

eliminate the free active species. The activities were apparently decreased by the ethanol washing treatment.

The order of activity of supported HPA was as follows: activated carbon $>$ titania $>$ alumina $>$ silica $>$ zeolite $>$ zirconia $>$ magnesia $\approx 0$

3. 2. HTS for Additives of Supported HPA Catalyst $8 \mathrm{mg}$ HPA was charged with $5 \mu \mathrm{mol}$ additive salt in $1 \mathrm{~mL}$ ethanol and then $50 \mathrm{mg}$ activated carbon was impregnated. Ethanol washing treatment was eliminated to avoid the loss of additives. The weight of the HPA charge was determined because the weight of supported HPA on the activated carbon B was $0.2 \mathrm{~g} / \mathrm{g}$-carbon after ethanol washing. Without the additives, the yields of benzyl anisoles and benzyl ether were $58.2 \%$ and $4.7 \%$, respectively. The results of screening are summarized in Table 2.

The 5 principal components of the physicochemical properties of the elements and the activities were used to tune the internal parameters of RBFN or SVM. After these properties and activities were correlated, RBFN and SVM could predict the activity of other additives on activated carbon. The order of activity predicted by $\mathrm{RBFN}$ was: $\mathrm{Bi}>\mathrm{W}>\mathrm{Re}>\ldots>\mathrm{Pd}>\ldots>$ $\mathrm{Sn}$, whereas that predicted by $\mathrm{SVM}$ was: $\mathrm{W}>\mathrm{Bi}>\mathrm{Pd}$ $>\operatorname{Re}>$ Sn. Both methods suggest that addition of $\mathrm{Bi}$ or Re would increase the product yield as shown in Table 3.

According to the activity test for validation of these predictions, yields of benzyl anisoles were $59.4 \%$ and $64.1 \%$ for $\mathrm{Bi}$ and $\mathrm{Re}$, respectively. Therefore, catalyst containing $\mathrm{Re}$ was identified as a result of virtual screening by RBFN or SVM, although the activity was 

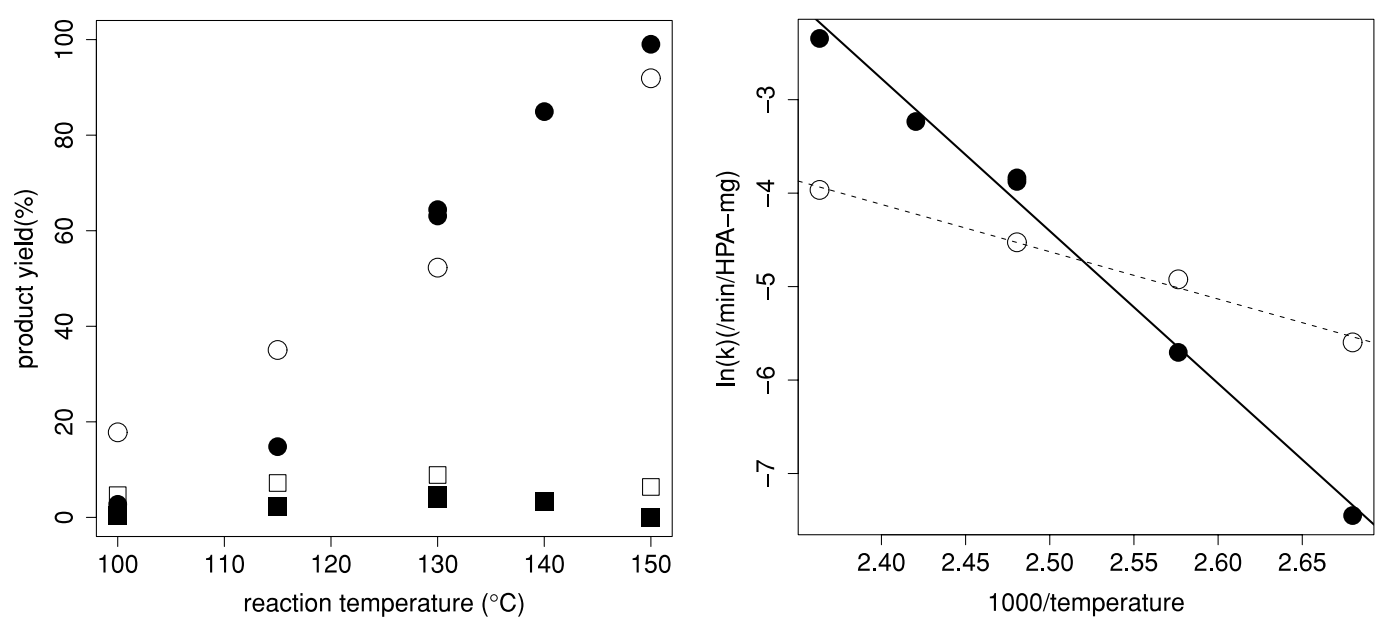

Circles: benzyl anisoles, squares: benzyl ether. Closed symbols: Re-HPA/AC, open symbols: HPA.

Fig. 3 Effect of Reaction Temperature on the Activity of Re-HPA/AC

rather higher than predicted.

\section{3. Activity of Re-HPA/AC Catalyst}

The effect of reaction temperature on the activity of Re-HPA/AC catalyst was investigated. The yield of benzyl anisoles increased rapidly over $120^{\circ} \mathrm{C}$. The pseudo-first order rate constant of anisole formation was determined and the specific activation energy was estimated as $135.6 \mathrm{~kJ} / \mathrm{mol}$ as shown in Fig. 3. This value is almost the same as that of clay supported catalyst ${ }^{1)}$, which suggests that the diffusion steps are not rate-determining. HPA catalyst without support has an activation energy of $42.1 \mathrm{~kJ} / \mathrm{mol}$. The supported HPA showed much higher activity at high temperature, whereas the homogeneous HPA catalyst had higher activity under $120^{\circ} \mathrm{C}$. The difference between these activation energies suggest that the contribution of liberated HPA from activated carbon is small in the activity of Re-HPA/AC catalyst.

\section{Conclusion}

Screening of a new catalyst for Friedel-Crafts benzylation of anisole was conducted using a HTS system and data mining tools. Many types of supports for HPA catalyst were screened in a short time, and an activated carbon supported phosphotungstate salt was discovered to show high activity. The relationship between the physicochemical properties of cation and the activity was quantified using a radial basis function network or support vector machine. These methods showed that the combination of Re and HPA on activated carbon provide optimum catalysis for the reaction, which was confirmed by experimental results.

\section{Acknowledgment}

This work was supported by a Grant-in-Aid for Challenging Exploratory Research (22656183).

\section{Appendix}

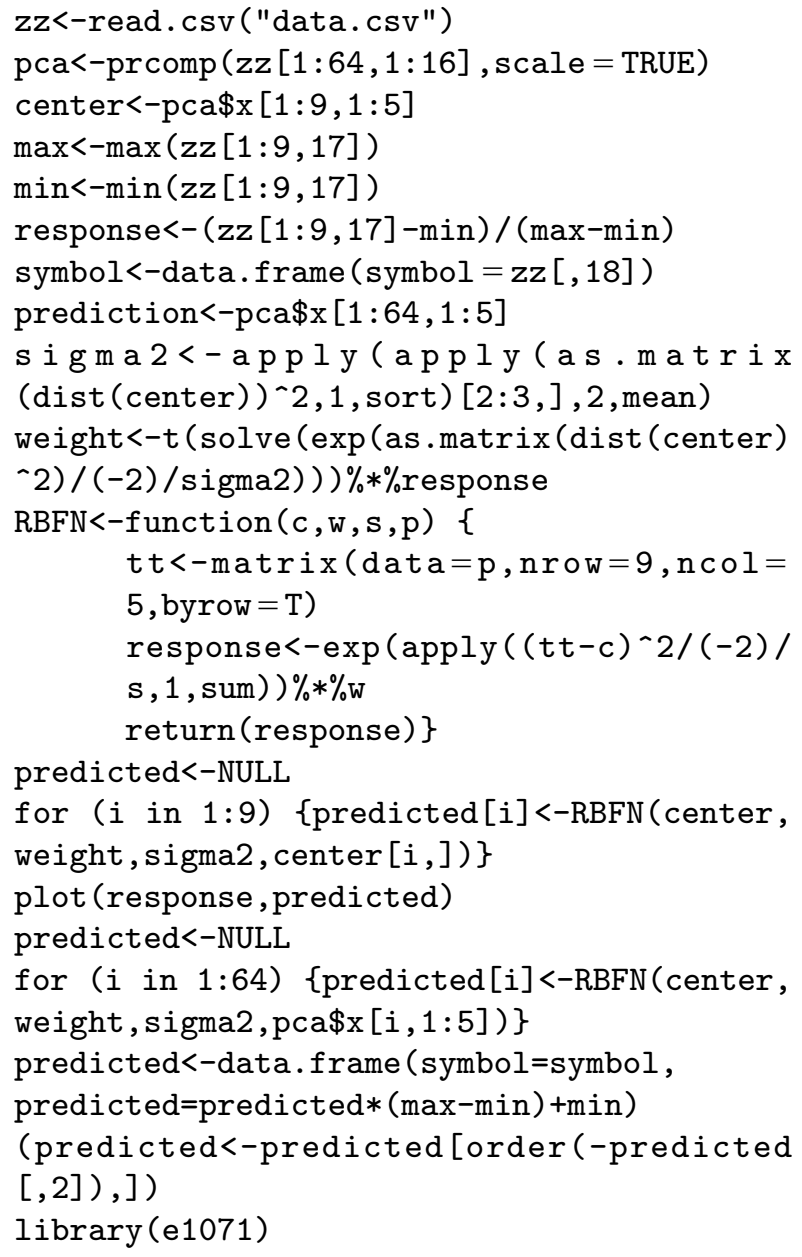

J. Jpn. Petrol. Inst., Vol. 54, No. 2, 2011 


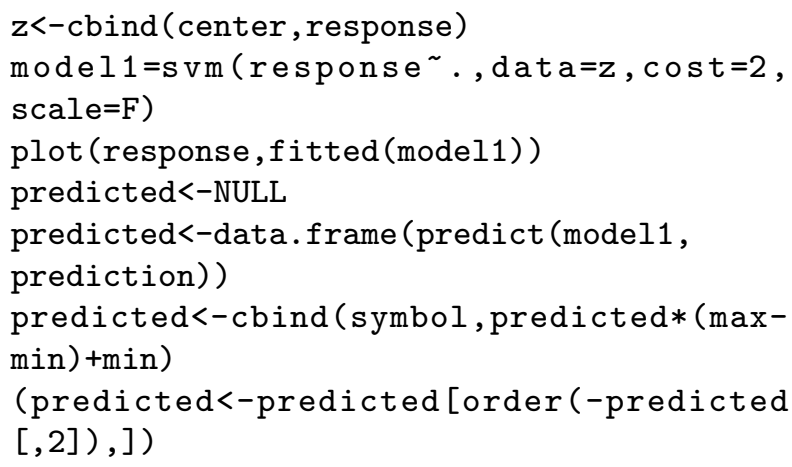

\section{References}

1) Cseri, T., Békássy, S., Figueras, F., Rizner, S., J. Mol. Catal. A., 98, (2), 101 (1995).

2) Singh, D. U., Samant, S. D., J. Mol. Catal. A., 223, (1-2), 111 (2004).

3) Freese, U., Heinrich, F., Roessner, F., Catal. Today, 49, (1-3), 237 (1999)

4) Anand, C., Srinivasu, P., Alam, S., Balasubramanian, V. V., Sawant, D. P., Palanichamy, M., Murugesan, V., Vinu, A., Microporous Mesoporous Mater, 111, (1-3), 72 (2008).

5) Yamashita, K., Hirano, M., Okumura, K., Niwa, M., Catal. Today, 118, (3-4), 385 (2006)

6) Shishido, T., Kitano, T., Teramura, K., Tanaka, T., Catal. Lett., 129, (3), 383 (2009).

7) Omata, K., Yamazaki, Y., Kobayashi, Y., Yamada, M., J. Combi. Chem., 12, (4), 435 (2010).
8) Omata, K., Yamazaki, Y., Kobayashi, Y., Yamada, M., J. Jpn. Petrol. Inst., 53, (5), 303 (2010).

9) Omata, K., Nagao, D., Yamada, M., J. Jpn. Petrol. Inst., 54, (1), 30 (2011).

10) Omata, K., Yamada, M., Ind. Eng. Chem. Res., 43, (20), 6622 (2004).

11) Omata, K., Hashimoto, M., Sutarto, Ishiguro, G., Watanabe, Y., Umegaki, T., Yamada, M., J. Jpn. Petrol. Inst., 48, (3), 145 (2005).

12) Omata, K., Sutarto, Hashimoto, M., Ishiguro, G., Watanabe, Y., Umegaki, T., Yamada, M., Ind. Eng. Chem. Res., 45, (14), 4905 (2006).

13) Omata, K., Kobayashi, Y., Yamada, M., Catal. Today, 117, (13), 311 (2006).

14) Omata, K., Endo, Y., Ishii, H., Masuda, A., Yamada, M., Appl. Catal. A.: General, 351, (1), 54 (2008).

15) Omata, K., Masuda, A., Ishii, H., Suzuki, H., Yamada, M., Appl. Catal. A.: General, 362, (1-2), 14 (2009).

16) Omata, K., Kobayashi, Y., Yamada, M., Energy \& Fuels, 23, 1931 (2009).

17) Kobayashi, Y., Omata, K., Yamada, M., Ind. Eng. Chem. Res., 49, 1541 (2010).

18) R Development Core Team. R Foundation for Statistical Computing, Vienna, Austria (2009), ISBN 3-900051-07-0.

19) Periodic Table $X$ is downloadable from the site of Synergy Creations.

20) Barin, I., Sauert, F., Schultze-Rhonhof, S., Sheng, W. S., "Thermochemical data of pure substances (2nd ed.)," $\mathrm{VCH}$, Weinheim (1993).

21) Kin, M., "Data Science by R,” Morikita Publishing, Tokyo (2007).

要旨

$$
\text { ハイスループットスクリーニングとデータマイニングによる }
$$

\title{
Friedel-Crafts 反応用へテロポリ酸触媒の担体および添加物の探索
}

\author{
小俣＼cjkstart光司 \\ 東北大学大学院工学研究科応用化学専攻, 980-8579 仙台市青葉区荒巻字青葉6-6-07
}

Friedel-Crafts 反応は種々の中間体の合成や石油化学プロセス に欠かせない反応であるが，プロセスのグリーン化に対応した 固体触媒の開発が求められているため, 各種の HTS（HighThroughput Screening）反応器を作製してベンジルアルコールに よるアニソールのベンジル化反応用の固体触媒の探索を進めて いる。本研究では 12 タングストリン酸（HPA）触媒に適した
担体を探索した後，担持触媒への最適添加元素をデータマイニ ングッールを用いてさらに探索した。添加物元素の物性值の主 成分と活性の関係をラジアル基底関数ネットワークならびにサ ポートベクターマシーンにより定量的に求めた結果, 活性炭に 担持した HPA にRe を添加した場合に高活性を示すことを見出 した。 